THE GLOBE PLAYHOUSE 
LONDON : HUMPHREY MILFORD

OXFORD UNIVERSITY PRESS 



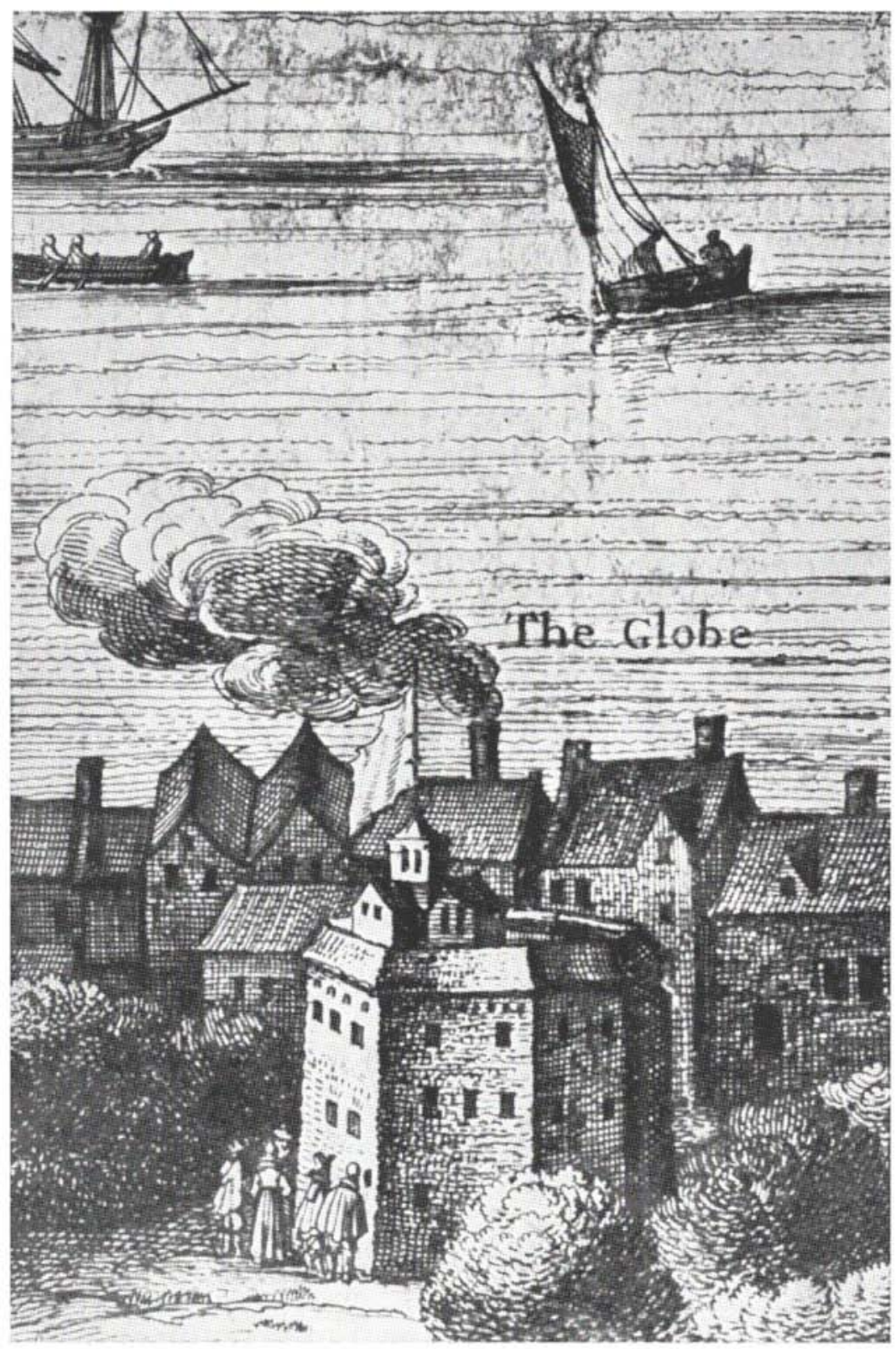

THE GLOBE PLAYHOUSE

Detail from Visscher's "View of London," 1606-1614

From the unique original in the Folger Shakespeare Library 


\section{THE GLOBE PLAYHOUSE}

Its Design and Equipment

By JOHN CRANFORD ADAMS

HARVARD UNIVERSITY PRESS CAMBRIDGE, MASSACHUSETTS

$$
1942
$$


COPYRIGHT, 1942

BY THE PRESIDENT AND FELLOWS OF HARVARD COLLEGE

PRINTED AT THE HARVARD UNIVERSITY PRINTING OFFICE CAMBRIDGE, MASS., U.S.A. 